CESIS Electronic Working Paper Series

Paper No. 261

Ethnic origin, local labour markets and self-employment in Sweden: A Multilevel Approach

\author{
Lina Andersson \\ Mats Hammarstedt \\ Shakir Hussain \\ Ghazi Shukur
}

November 2011 


\title{
Ethnic origin, local labour markets and self-employment in Sweden: A Multilevel Approach
}

\author{
Lina Andersson \\ Department of Economics and Statistics \\ Linnaeus University \\ SE-351 95 Växjö \\ Sweden \\ lina.andersson@1nu.se \\ Ghazi Shukur \\ Department of Economics, Finance and \\ Statistics \\ Jönköping International Business School \\ SE- 55111 Jönköping \\ Sweden \\ ghazi.shukur@jibs.hj.se \\ $\&$ \\ Department of Economics and Statistics \\ Linnaeus University \\ SE-351 95 Växjö \\ Sweden \\ ghazi.shukur@lnu.se
}

Mats Hammarstedt

Department of Economics and Statistics

Linnaeus University

SE-351 95 Växjö

Sweden

mats.hammarstedt@lnu.se

Shakir Hussain

School of Medicine

University of Birmingham

Birmingham

United Kingdom

s.hussain@bham.ac.uk

\begin{abstract}
We investigate the importance of ethnic origin and local labour markets conditions for selfemployment propensities in Sweden. In line with previous research we find differences in the self-employment rate between different immigrant groups as well as between different immigrant cohorts. We use a multilevel regression approach in order to quantify the role of ethnic background, point of time for immigration and local market conditions in order to further understand differences in self-employment rates between different ethnic groups. We arrive at the following: The self-employment decision is to a major extent guided by factors unobservable in register data. Such factors might be i.e. individual entrepreneurial ability and access to financial capital. The individual's ethnic background and point of time for immigration play a smaller role for the self-employment decision but are more important than local labour market conditions.
\end{abstract}

Keywords: Self-employment, immigrant background, local labour market

JEL-codes: J15, R23 


\section{Introduction}

Are immigrants over-represented in self-employment compared to natives and do immigrants have other reasons than natives for becoming self-employed? The questions have gained increased attention in research in economics as well as in other disciplines. High selfemployment rates among the foreign born population have been documented in several OECD-countries. ${ }^{1}$ Furthermore, several explanations for why immigrants are overrepresented in self-employment compared to natives, such as traditions from the home country, the existence of ethnic enclaves, high rates of unemployment, different kinds of discrimination and family traditions, have also been put forward in the literature. ${ }^{2}$

However, it has also been put forward that self-employment opportunities may arise not only as a result of one single factor but instead of the fact that many different aspects meet in an intersection facilitating immigrant self-employment, often referred to as the mixed embeddedness approach. ${ }^{3}$ Thus, immigrants may be over-represented in self-employment as a result of the interplay between factors such as personal resources, local market opportunities and the economic environment.

In this paper we depart from the view that the interplay between social, economic and institutional contexts are decisive for immigrant self-employment opportunities and explore the extent to which differences in self-employment rates between immigrants and natives as well as between different immigrant groups can be explained by the immigrants ethnic origin, their point of time for immigration and economic conditions at the local market where the self-employed individuals are active.

Our empirical analysis is carried out with the help of multilevel regression. Multilevel modelling is suitable when the data consists of units (e.g. individuals) that are grouped at different levels. Here, individuals are nested within different regions of origin, different points of time for immigration and different local labour markets. Multilevel analysis allows us to quantify such grouping effects and therefore we use logistic multilevel regression models to estimate the probability of being self-employed in 2007.

Few previous attempts have been made to elucidate the extent to which self-employment among immigrants is affected by the mix of personal resources, local market opportunities and the economic environment. One such attempt is found in Ohlsson, Broomé \& Bevelander (2011) who found that individual to a larger extent than ethnic and social characteristics are affecting self-employment propensities among immigrants. However, we extend the work by Ohlsson, Broomé \& Bevelander (2011) since we consider the fact that the self-employment propensity may also differ within ethnic groups due to differences in time of immigration to Sweden. Since the character of immigration to Sweden has changed considerably over time we have good reasons to believe that there are differences in self-employment propensities not only between different ethnic groups but also within certain groups with respect to their point

\footnotetext{
${ }^{1}$ See e.g. Borjas (1986), Fairlie \& Meyer (1996), Fairlie (1999) Hout \& Rosen (2000) and Fairlie \& Robb (2007) for studies from the US, Le (2000) for a study from Australia, Clark \& Drinkwater (2000) for a study from the UK, Constant \& Zimmermann (2006) for a study from Germany and Hammarstedt $(2001,2006)$ and AnderssonJoona (2010) for studies from Sweden.

${ }^{2}$ See e.g. Borjas (1986), Yuengert (1995), Fairlie \& Meyer (1996), Clark \& Drinkwater (2000), Hammarstedt (2001a), Hammarstedt \& Shukur (2009) and Andersson \& Hammarstedt (2010, 2011).

${ }^{3}$ See e.g. Kloosterman, van der Leun \& Rath (1998), Kloosterman \& Rath (2001) and Ram, Theodorakopoulus \& Jones (2008).
} 
of time for immigration. Therefore, we explore the combined influence of ethnic origin and year of immigration to Sweden rather than the influence of ethnic origin only.

The results in our empirical study reveal that the self-employment decision to a major extent is guided by individual factors unobservable in register data. Such factors might be e.g. individual entrepreneurial ability and access to financial capital. The individual's ethnic background and point of time for immigration play a smaller role but are more important than local market conditions for the self-employment decision.

The remainder of the paper has the following structure: Section 2 gives an overview of the immigrant population in Sweden. Data and some descriptive statistics are presented in Section 3. Our empirical strategy and the results are presented in Section 4 while Section 5, finally, contains the conclusions.

\section{The immigrant population in Sweden}

Sweden, just as many other OECD countries, has experienced an increase in the share of immigrants during recent decades. In 2011 more than 12 per cent of the total population is foreign born. In addition to the increase in the immigrant population, the character of immigration has also changed. During the Second World War refugee immigrants arrived from Estonia and Latvia and after the Second World War and at times during the 1950s and 1960s there was refugee immigration to Sweden from different countries in Eastern Europe. These immigrants were in general highly educated and did well in the Swedish labour market. Labour-force migration to Sweden started during the second half of the 1940s, increased during the 1950s and lasted primarily until the mid-1970s as a result of Sweden's industrial and economic expansion. The labour-force migration was made possible by institutional changes which removed the needs for residence and work permits for immigrants from the Nordic countries and made it possible for non-Nordic immigrants to enter Sweden individually and then apply for a work permit. The labour-force migration during the 1950s and 1960s consisted primarily of people from Finland, Norway and Denmark and from countries in Southern Europe. The great majority of the labour-force migrants from Southern Europe came from Yugoslavia, Italy and Greece. There was also labour-force migration from Nordic countries other than Finland and from countries in Western Europe. Labour-force migrants from these countries were in general better educated than labour-force migrants from Finland or Southern Europe. The labour-force migrants did well in the Swedish labour market and during the 1950s as well as the 1960s; the employment rate was often higher and the unemployment lower among immigrants than among native Swedes.

In the mid-1960s Swedish labour organisations saw immigrants keeping wages low for less skilled workers. A more restrictive immigration policy and a deterioration in the labour market caused the character of immigration to change during the 1970s. As labour-force migration tapered off, the number of refugees started to increase. In the mid-1970s, refugee migration from Latin America started to reach significant proportions and during the 1980s and 1990s a great number of refugees came from Asia and Africa. During the 1990s and at the beginning of the 2000s, refugee immigration to Sweden has continued to increase; the influx during the 1990s was dominated by refugees from the former Yugoslavia and the Middle East while the influx during the early 2000s was dominated by Middle Eastern refugees.

The new immigration has changed the composition of the immigrant population. In 1970, about 60 per cent of the foreign-born persons living in Sweden had been born in other Nordic 
countries and about 30 per cent in other European countries. Only about 10 per cent were born outside of Europe. In 2011 only about 30 per cent were born in other Nordic countries, about 30 per cent were born in other European countries and almost 40 per cent of the immigrant population was born in non-European countries. Among the immigrants from non-European countries the great majority are refugees from countries in Africa, Asia and the Middle East.

Early labour-force migrants did often well on the Swedish labour market and up to the mid1970s the average earnings and employment rates among immigrants were often higher than among the native population. However, self-employment was a marginal phenomenon among early labour force migrants in Sweden. ${ }^{4}$ Instead, a large increase in self-employment rates among immigrants has occurred during more recent years, especially among immigrants originating from certain countries in Southern Europe and the Middle East. ${ }^{5}$

Thus, large differences in self-employment rates between certain immigrant groups have been documented in previous research. Furthermore, there are also large differences in selfemployment rates within certain groups of immigrants depending on point of time for their immigration. ${ }^{6}$ Thus, when investigating the extent to which immigrant self-employment is affect by personal resources, local market opportunities and the economic environment there are good reasons to divide the immigrants not only by their ethnic origin but also by their point of time for immigration.

\section{Data and some descriptive statistics}

We use data from the register-based longitudinal data base LISA (Longitudinal Integration Database for Health Insurance and Labour Market Studies) developed by Statistics Sweden. LISA contains information on everyone in Sweden, 16 years and older, and his or her demographic characteristics, labour market characteristics and use of social benefits. We include all foreign-born individuals resident in Sweden in 2007 and a 10-per cent random sample of the native population resident in Sweden in $2007 .^{7}$ The analysis focuses on individuals aged between 20 and 64 years old. Students and early retired are excluded. These selections are made in order to obtain a sample consisting of individuals who are active on the labour market. In line with previous research on self-employment, we leave out farmers from the analysis. Our total sample then consists of 987,435 individuals out of whom 659,040 are foreign born and 328,395 are natives.

We define an individual as self-employed if he or she was registered as employed and if he or she was registered as self-employed by Statistics Sweden in 2007. Statistics Sweden uses information on labour earnings from the month of November to determine whether an individual is wage-employed or self-employed. An individual is defined as self-employed if earnings from self-employment constituted that person's main source of income in November. This means that if a person has earnings from both self-employment and wage employment, he/she is registered as self-employed if self-employment earnings exceed wage earnings and as wage-employed if wage earnings are larger than earnings from self-employment. We include both private firms and limited liability companies.

\footnotetext{
${ }^{4}$ See Hammarstedt (2001b).

${ }^{5}$ See Hammarstedt (2001b, 2004, 2006) and Andersson \& Hammarstedt (2011b).

${ }^{6}$ See Hammarstedt (2004).

${ }^{7}$ Individuals who are born in Sweden and whose parents are born in Sweden are defined as natives. Secondgeneration immigrants are thus excluded from the analysis.
} 
In order to explore the importance of origin for the self-employment decision we divide the immigrants into eight groups based on their region of origin: Nordic countries, Western Europe, Eastern Europe, Southern Europe, the Middle East, Africa, Asia and Latin America. We also want to consider the fact that immigrants within a certain group immigrated to Sweden at different points in time. Therefore, for each region we divide the individuals into seven groups, cohorts, on the basis of the year of immigration to Sweden: those who arrived before 1976, between 1976 and 1980, between 1981 and 1985, between 1986 and 1990, between, 1991 and 1995, between 1996 and 2000, between 2001 and 2007. In total then we have 57 groups: 56 immigrant groups $(8 \times 7)$ and natives.

We also divide the individuals in our data into groups on the basis of their region of residence in order to study the effect of the local business environment. For this purpose we use Statistics Sweden's regional division of Sweden into local labour markets; in 2007 there were 87 local labour markets in Sweden. ${ }^{8}$ The regional division is based on statistics of commuting patterns between municipalities. Based on these statistics, local labour markets are created by identifying local centres (independent municipalities) and by linking dependent municipalities to these centres. ${ }^{9}$

Table 1: Descriptive statistics of individuals aged 20 to 64 in 2007, by gender and employment status.

\begin{tabular}{lcccc}
\hline \hline & \multicolumn{2}{c}{ Men } & \multicolumn{2}{c}{ Women } \\
\cline { 2 - 5 } & Self-employed & $\begin{array}{c}\text { Not self- } \\
\text { employed }\end{array}$ & Self-employed & $\begin{array}{c}\text { Not self- } \\
\text { employed }\end{array}$ \\
\hline Age & $45.7(10.3)$ & $41.5(11.9)$ & $45.3(10.6)$ & $41.7(11.7)$ \\
Educational attainment & & & & \\
Primary school & $23.3(42.2)$ & $19.3(39.5)$ & $17.0(37.6)$ & $17.3(37.9)$ \\
Secondary school & $47.6(49.9)$ & $46.1(49.8)$ & $45.9(49.8)$ & $42.7(49.5)$ \\
University degree & $29.2(45.4)$ & $34.6(47.6)$ & $37.1(48.3)$ & $39.9(49.0)$ \\
Married & $61.0(48.8)$ & $47.5(49.9)$ & $62.2(48.5)$ & $52.6(49.9)$ \\
Children & $59.4(49.1)$ & $48.7(50.0)$ & $60.4(48.9)$ & $58.8(49.2)$ \\
Region of origin & & & & \\
Sweden & $36.4(48.1)$ & $33.8(47.3)$ & $34.0(47.4)$ & $32.3(46.8)$ \\
Nordic countries & $11.0(31.3)$ & $12.1(32.6)$ & $15.2(35.9)$ & $14.7(35.4)$ \\
Western Europe & $7.1(25.7)$ & $6.4(24.5)$ & $7.3(26.1)$ & $4.7(21.3)$ \\
Eastern Europe & $5.4(22.7)$ & $5.4(22.7)$ & $10.7(30.9)$ & $9.0(28.7)$ \\
Southern Europe & $7.1(25.7)$ & $10.9(31.1)$ & $5.8(23.3)$ & $9.2(28.9)$ \\
The Middle East & $24.3(42.9)$ & $15.2(35.9)$ & $13.5(34.1)$ & $11.7(32.1)$ \\
Africa & $2.6(15.8)$ & $5.9(23.2)$ & $1.4(11.6)$ & $4.3(20.4)$ \\
Asia & $4.2(20.0)$ & $5.7(23.5)$ & $9.6(29.4)$ & $9.5(29.3)$ \\
Latin America & $1.9(13.7)$ & $4.6(21.0)$ & $2.6(15.9)$ & $4.5(20.7)$ \\
Number of observations & 47,718 & & & 453,673 \\
& & 465,759 & 20,285 & \\
\hline
\end{tabular}

Standard deviations are within parentheses.

\footnotetext{
${ }^{8}$ See Appendix A for a figure of the geographical division of the local labour markets in Sweden.

${ }^{9}$ See SCB, MIS 2007:1 for more information.
} 
Table 1 shows some descriptive statistics for the men and women included in our sample. It emerges for both men and women that self-employed individuals tend to be older than those who are not self-employed and they are also married and have children living in the household to a larger extent. As regards educational attainment, self-employed men appear to have a lower level of educational attainment than men who are not self-employed whereas the differences among women are less pronounced.

Next, Table 2 shows the self-employment rate of men and women by region of origin and by year of immigration. Table 2 reveals that the self-employment rate is higher for men than for women both among when the individuals are divided up by region of origin and year of immigration. For men the highest self-employment rate is found among immigrants originating from the Middle East followed by immigrants from Western Europe and natives. The lowest self-employment share is found among immigrants from Latin America and Africa. For women on the other hand, women from Western Europe have the highest selfemployment rate followed by Eastern European women. Just as for men, women from Africa and Latin America have the lowest self-employment rate. Turning to self-employment rate by year of immigration, Table 2 shows that, in general, and for men in particular, the selfemployment rate increases with length of residence in Sweden. This is not surprising since for example knowledge of labour markets, tastes of consumers and institutions as well as wealth increase with time spent in the host countries. ${ }^{10}$ Also, the character of the immigration to Sweden has changed considerably over time.

Table 2: Self-employment by region of origin and year of immigration in 2007 (aged 20-64), by gender

\begin{tabular}{lcclcc}
\hline \multirow{2}{*}{ Region of origin } & \multicolumn{2}{c}{ Self-employment rate (\%) } & \multicolumn{2}{c}{ Self-employment rate (\%) } \\
\cline { 2 - 6 } Sweden & Men & Women & Year of immigration & Men & Women \\
\hline Nordic countries & $9.9(29.9)$ & $4.5(20.7)$ & Immigrated before 1976 & $11.7(32.1)$ & $5.5(22.9)$ \\
Western Europe & $8.5(27.9)$ & $4.4(20.6)$ & Immigrated 1976-1980 & $13.7(34.4)$ & $5.5(22.8)$ \\
Eastern Europe & $10.2(30.2)$ & $6.4(24.6)$ & Immigrated 1981-1985 & $12.1(32.6)$ & $5.4(22.5)$ \\
Southern Europe & $9.3(29.0)$ & $5.0(21.8)$ & Immigrated 1986-1990 & $11.2(31.6)$ & $5.2(22.1)$ \\
The Middle East & $6.3(24.2)$ & $2.7(16.3)$ & Immigrated 1991-1995 & $8.5(27.9)$ & $3.7(18.8)$ \\
Africa & $14.1(34.8)$ & $4.9(21.6)$ & Immigrated 1996-2000 & $8.9(28.5)$ & $4.0(19.6)$ \\
Asia & $4.4(20.6)$ & $1.4(11.7)$ & Immigrated 2001-2007 & $4.2(20.0)$ & $2.5(15.6)$ \\
Latin America & $6.8(25.2)$ & $4.3(20.3)$ & & & \\
& $4.0(19.7)$ & $2.5(15.7)$ & & & \\
Number of observations & 513,477 & 473,958 & Number of observations & 513,477 & \\
& & & & & \\
\end{tabular}

Standard deviations are within parentheses.

One purpose of the paper is to assess the importance of region of origin and year of immigration on the decision to be self-employed. Figures 1 and 2 reveal that the selfemployment propensity varies among immigrant groups and that the self-employment propensity also varies within groups due to differences in the time of immigration to Sweden. Among men, immigrants from the Middle East are most likely to be self-employed and in particular those who immigrated to Sweden during the first half of the 1980s. Further, men with an Eastern European origin who immigrated to Sweden before 1991 have the lowest tendency to be self-employed in 2007. For women, those with a Middle Eastern origin and who immigrated to Sweden during 1976-1980 tend to be self-employed to a larger extent than

\footnotetext{
${ }^{10}$ See Parker (2004).
} 
the other group as well as Western European women who immigrated after the mid 1980s. The lowest share of self-employed is found for women from Asia who immigrated to Sweden after 1985. Generally, there is more variation among women than among men, both across and within groups.
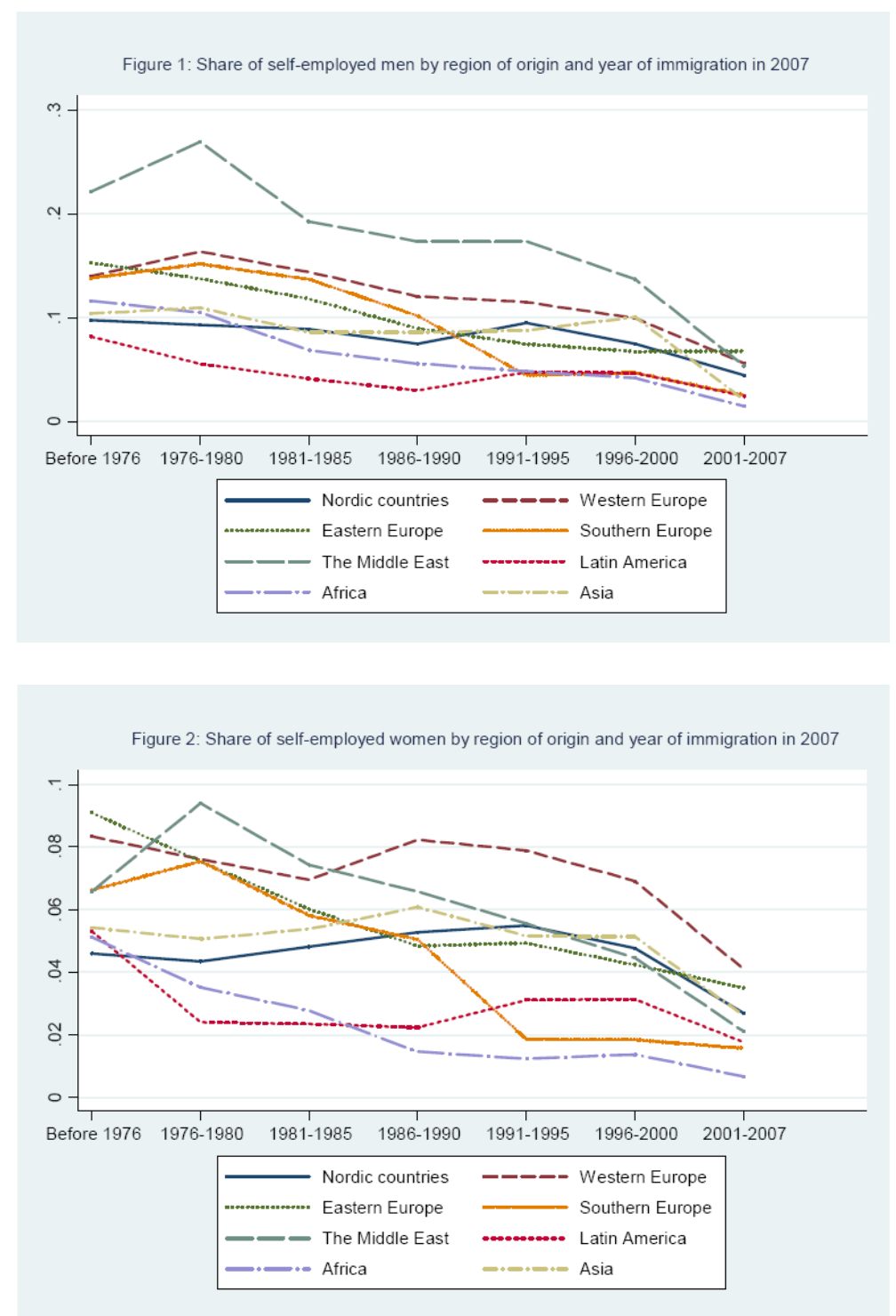

We are also interested in the importance of local labour market regions. Figures 3 and 4 show that share of self-employed indeed tend to vary among local labour market areas for both men and women, respectively, indicating that differences among local labour markets may be an important determinant of the propensity to be self-employed. 

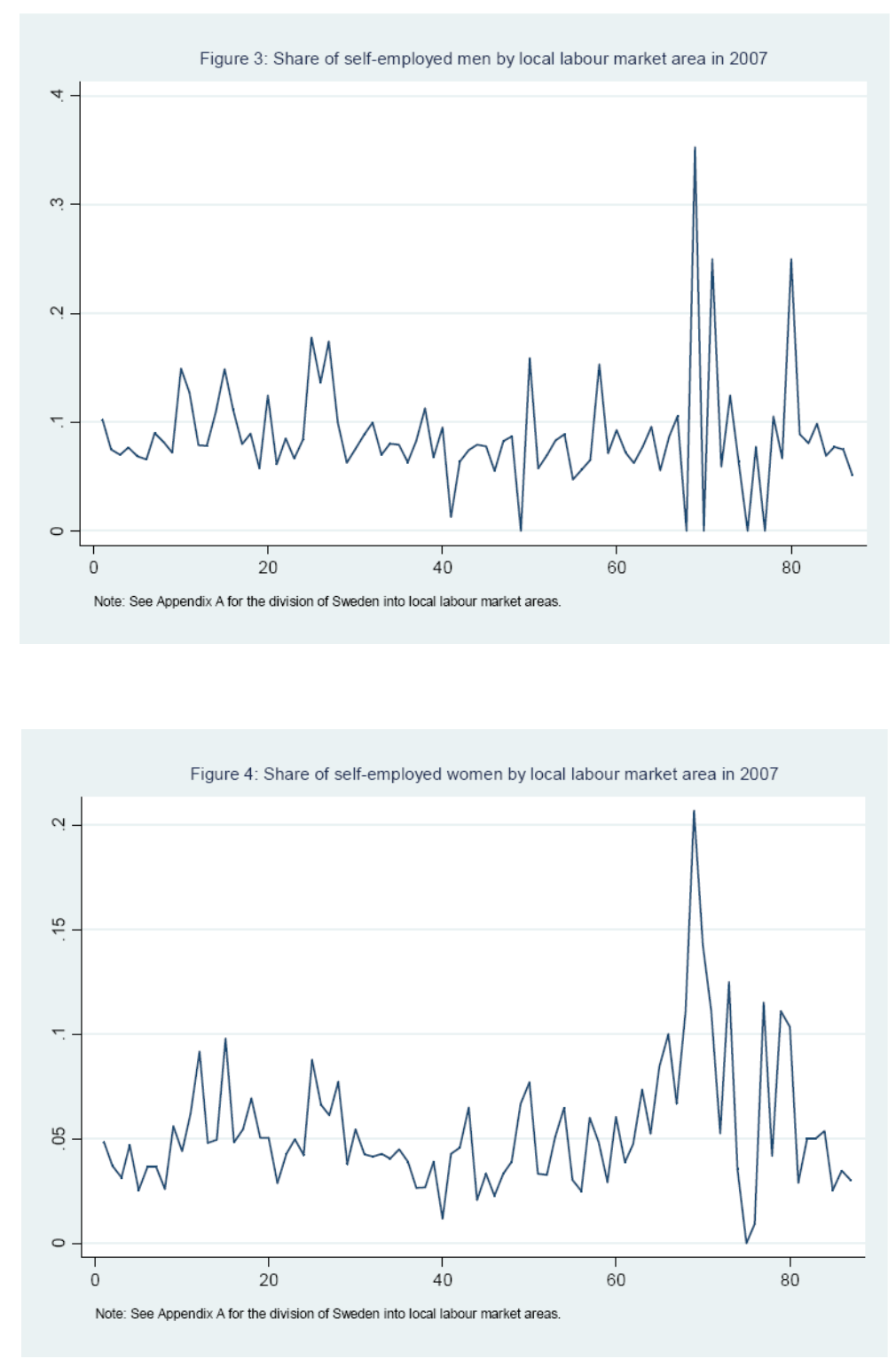

\section{Modelling self-employment}

\subsection{A multilevel regression approach}

We apply multilevel analysis in order to assess the importance of region of origin, time of arrival and local labour market conditions for explaining the observed variation an individual's decision of becoming self-employed. Multilevel modelling is appropriate when data is hierarchically structured, i.e. when it consists of units (e.g. individuals) grouped at different levels of a hierarchy. ${ }^{11}$ For example, groups tend to be differentiated in the sense that their members both influence and are influenced by the group membership. As a result, it is likely that individual outcomes are more correlated within a certain group (e.g. within a group sharing the same ethnic origin) than individual outcomes across different groups (e.g. origins). By applying multilevel analysis we are able to account for and also quantify such group effects.

\footnotetext{
${ }^{11}$ See Gelman \&Hill (2007). Data Analysis Using Regression and Multilevel/Hierarchical Models, New York: Cambridge
} 
In our data individuals are nested within different regions of origin/cohorts and also within different local labour markets. Units at one level are recognised as being grouped, or nested, within units at the next higher level. Since in our case individuals from the same region of origin and cohort can reside in different local labour markets, they are nested within overlapping hierarchies of regions of origin/cohorts and local labour market regions.

We estimate the probability of an individual to be self-employed in 2007 using a logistic multilevel model separately by gender. The response variable has a binary outcome for each individual and equals 1 if the individual is self-employed and 0 other wise. The model is set up as follows.

Let $y_{i}$ denote the dependent variable that equals 1 if the individual is self-employed and 0 otherwise. The probability model then becomes:

$$
\operatorname{Pr}\left(y_{i}\right)=\log \mathrm{it}^{-1}\left(\alpha_{j[i]}+\alpha_{k[i]}+B x_{i}\right), \text { for } i=1, \ldots, n
$$

where $x_{i}$ is a matrix of independent variables (individual-level predictors) that might affect the probability of being self-employed and $B$ is an associated vector of coefficients. In our case we use age, age squared, educational attainment (dummy variables), marital status, and incidence of children living in the household. We have two grouping factors, namely local labour markets and region of origin/cohort. $\alpha_{j[i]}$ is a random effect for local labour markets with the indices $j[i]$ indicating that individual $i$ is nested within group $j$. In other words, this means that an individual $i$ is nested within a local labour market area $j$. On the other hand, $\alpha_{k[i]}$ is a random effect for region of origin/cohort where an individual $i$ is now nested within an immigrant group and cohort $(k)$. The random effects for labour market regions and region of origin, respectively, are modelled as follows:

$$
\begin{aligned}
& \alpha_{j}=\lambda_{0}+\gamma_{1} u_{j}+\eta_{j}, \text { with } \eta_{j} \sim N\left(0, \sigma_{\alpha_{j}}^{2}\right), \text { for } j=1, \ldots, J \\
& \alpha_{k}=\lambda_{0}+\varepsilon_{k}, \text { with } \varepsilon_{k} \sim N\left(0, \sigma_{\alpha_{k}}^{2}\right), \text { for } k=1, \ldots, K
\end{aligned}
$$

where $\lambda_{0}$ is the overall probability of being self-employed (relative to not being selfemployed). A positive estimate of $\mathrm{X}$ indicates that the probability of being self-employed is larger than the probability of being wage-employed. Further, $u_{j}$ is a matrix of independent variables (local labour market predictors) that might affect self-employment propensities. Here, we included controls for local unemployment rate and local income tax rate. The error terms $\eta_{j}$ and $\varepsilon_{k}$ are the deviation of the different groups from the overall self-employment propensity. These error terms are normally distributed with mean 0 and variance $\sigma_{\alpha_{j}}^{2}$ and $\sigma_{\alpha_{k}}^{2}$. The multiple random intercepts are modelled independently and we assume that the individual $i$ is one time nested within $j$ and the second time within $k$, independently.

In order to assess how much of the total variation in self-employment propensities that can be attributed to differences between local labour market regions and differences between different immigrants groups, we make use of the estimated variance of the random intercepts to calculate intra class correlations (ICC). The ICC is calculated as follows: 
$I C C=\frac{\sigma_{\alpha_{j}}^{2}+\sigma_{\alpha_{k}}^{2}}{\sigma_{\alpha_{j}}^{2}+\sigma_{\alpha_{k}}^{2}+\pi^{2} / 3}$

where $\sigma_{\alpha_{j}}^{2}$ is the variance for local labour market and $\sigma_{\alpha_{k}}^{2}$ is the variance for region of origin. Since we apply a logistic multilevel model the individual errors follow a logistic distribution. In this case, the individual variance is equal to $\pi^{2} / 3$, i.e. to 3.29. The ICC shows the proportion of the total variance that can be explained by group differences in the population, i.e. by differences between local labour market regions and between regions of origin and point of time for immigration (cohorts). ${ }^{12}$

We estimate five different specifications. Specification 1 simply includes a random effect for region of origin and time of immigration, i.e. in this model individuals are nested within different regions of origin and cohorts. In Specification 2, we add individual characteristics, i.e. age, aged squared, educational attainment, marital status, and incidence of children in the household, to Specification 1 in order to asses how individual heterogeneity affects the variance for region of origin. Specification 3 includes a random intercept for region of origin/cohort and local labour market area, respectively. In Specification 4 we add individuallevel predictors to Specification 3. Finally, in Specification 5 we also include local labour market characteristics, more precisely local unemployment rate and local income tax rate. ${ }^{13}$ By adding these local labour market predictors, we aim to control for possible differences in economic conditions for self-employment among the local labour market regions. The influence of local labour markets on self-employment propensities may then be interpreted as the effect of local entrepreneurial climate.

\subsection{Estimation results}

The results from the multilevel logistic regressions for males and females are presented in Table 3 and Table 4, respectively, while the differences in self-employment propensity between different immigrant groups and natives are highlighted by Figure B1 and Figure B2 in the Appendix. ${ }^{14}$ Figure B1 and B2 show the estimated random effects for region of origin and time of immigration. The dots (random effect) show each group's deviation from and the groups' distribution around the overall self-employment propensity (fixed effect). Thus, random effects close to zero, indicated by the bold line in the figures imply small deviations from the overall self-employment probability and random effects to the left and to the right of the bold line indicate a lower and a higher self-employment propensity, respectively, than on average.

Figure B1 reveals a high self-employment propensity among immigrants from the Middle East; immigrant cohorts from the Middle East have a higher self-employment propensity than the average with exception for the 2001-2007 cohort. We find relatively low self-employment propensities among immigrants from Africa and Latin America. For Southern European immigrants, the self-employment propensity is relatively high among early immigrant cohorts while relatively low for more recent cohorts. Irrespectively of origin, we find that the self-

\footnotetext{
${ }^{12}$ See Hox (2002).

${ }^{13}$ Appendix C presents qq-plots of the two random effects for men and women, respectively. The plots indicate that the distributions of the random effects fairly scattered around the assumed normal distribution.

${ }^{14}$ The corresponding figures for how self-employment differs between different labour market areas are available from the authors upon request.
} 
employment propensity is very low for the 2001-2007 cohort, a result that reflect the fact that it takes time in a new country to acquire financial capital, knowledge and resources needed to succeed as self-employed and that also stress the importance of considering point of time for immigration when immigrant self-employment propensities are analysed.

Turning to the ICC (total) in Table 3, we find that about 15 per cent (16.5 per cent in Specification 1 and 14.3 per cent in Specification 2) of the total variance in the propensity of being self-employed is explained by ethnic origin and point of time for immigration. When we add a random effect for local labour market areas in the estimations (Specification 3), it emerges that about 20 per cent of the total variance in the self-employment propensity (20.3 per cent in Specification 3, 18.2 per cent in Specification 4 and 18.2 per cent in Specification 5 ) is explained by differences by ethnic origin, point of time for immigration and between local labour market areas. However, the relative sizes of the variances of the group factors show that differences between regions of origin and point of time of immigration are important determinants than differences between local labour market areas.

Table 3: Multilevel logistic regression of the probability of being self-employed in 2007 for men

\begin{tabular}{|c|c|c|c|c|c|}
\hline & Specification 1 & Specification 2 & Specification 3 & Specification 4 & Specification 5 \\
\hline Intercept & $\begin{array}{l}-2.4048^{* \star *} \\
(0.0866)\end{array}$ & $\begin{array}{l}-6.1538^{* \star *} \\
(0.1089)\end{array}$ & $\begin{array}{r}-2.4195^{\star \star *} \\
(0.0897)\end{array}$ & $\begin{array}{l}-6.1962^{\star * \star} \\
(0.1114)\end{array}$ & $\begin{array}{l}-6.1482^{\star \star *} \\
(0.8783)\end{array}$ \\
\hline \multicolumn{6}{|l|}{ Individual characteristics } \\
\hline Age & - & $\begin{array}{c}0.1510^{* * *} \\
(0.0038)\end{array}$ & - & $\begin{array}{c}0.1507^{* * *} \\
(0.0038)\end{array}$ & $\begin{array}{c}0.1507^{\star * *} \\
(0.0038)\end{array}$ \\
\hline Age squared & - & $\begin{array}{l}-0.1449^{* * *} \\
(0.0042)\end{array}$ & - & $\begin{array}{l}-0.1445^{\star * *} \\
(0.0043)\end{array}$ & $\begin{array}{l}-0.1445^{\star * *} \\
(0.0043)\end{array}$ \\
\hline Primary school & - & Reference & - & Reference & Reference \\
\hline Secondary school & - & $\begin{array}{c}-0.1255^{* * *} \\
(0.0128)\end{array}$ & - & $\begin{array}{c}-0.1238^{* * *} \\
(0.0128)\end{array}$ & $\begin{array}{c}-0.1238^{* * *} \\
(0.0128)\end{array}$ \\
\hline University degree & - & $\begin{array}{c}-0.3732^{* * *} \\
(0.0141)\end{array}$ & - & $\begin{array}{c}-0.3903^{\star * *} \\
(0.0141)\end{array}$ & $\begin{array}{c}-0.3903^{* * *} \\
(0.0141)\end{array}$ \\
\hline Married & - & $\begin{array}{l}0.2615^{* * \star} \\
(0.0112)\end{array}$ & - & $\begin{array}{c}0.2672^{\star * *} \\
(0.0114)\end{array}$ & $\begin{array}{c}0.2671^{* * *} \\
(0.0114)\end{array}$ \\
\hline Children & - & $\begin{array}{l}0.2469^{\star * *} \\
(0.0114)\end{array}$ & - & $\begin{array}{l}0.2483^{* * \star} \\
(0.0114)\end{array}$ & $\begin{array}{c}0.2483^{* \star *} \\
(0.0114)\end{array}$ \\
\hline \multicolumn{6}{|l|}{$\begin{array}{l}\text { Local labour market } \\
\text { characteristics }\end{array}$} \\
\hline Local unemployment rate & - & - & - & - & $\begin{array}{l}-0.0046 \\
(0.0254)\end{array}$ \\
\hline Local income tax rate & - & - & - & - & $\begin{array}{l}-0.0011 \\
(0.0276)\end{array}$ \\
\hline $\begin{array}{l}\text { Variance region of origin and } \\
\text { year of immigration }\end{array}$ & 0.65 & 0.55 & 0.65 & 0.55 & 0.55 \\
\hline Variance labour market area & - & - & 0.19 & 0.18 & 0.18 \\
\hline Total variance & 0.65 & 0.55 & 0.84 & 0.73 & 0.73 \\
\hline ICC (total) & $16.5 \%$ & $14.3 \%$ & $20.3 \%$ & $18.2 \%$ & $18.2 \%$ \\
\hline DIC & 306,150 & 298,774 & 305,670 & 298,223 & 298,223 \\
\hline Number of observations & & & 513,477 & & \\
\hline
\end{tabular}


Thus, our results for males show that about 80 per cent of the variation is explained by individual factors other than those controlled for in the estimations. Such factors might i.e. be individual entrepreneurial ability and access to financial capital. Further, since we are only controlling for local unemployment rate and local income tax rate differences in selfemployment propensities might also be driven by circumstances on the local market that we have not controlled for. Since we are studying immigrants we cannot rule out the fact that i.e. customer discrimination plays a role for the possibilities to become and to survive as selfemployed.

Table 4: Multilevel logistic regression of the probability of being self-employed in 2007 for women, coefficients

\begin{tabular}{|c|c|c|c|c|c|}
\hline & Specification 1 & Specification 2 & Specification 3 & Specification 4 & Specification 5 \\
\hline Intercept & $\begin{array}{l}-3.1348^{* * *} \\
(0.0782)\end{array}$ & $\begin{array}{l}-6.1254^{\star * *} \\
(0.1387)\end{array}$ & $\begin{array}{l}-3.1537^{\star * *} \\
(0.0826)\end{array}$ & $\begin{array}{l}-6.1795^{\star * *} \\
(0.1414)\end{array}$ & $\begin{array}{l}-6.3693^{\star * *} \\
(0.9961)\end{array}$ \\
\hline \multicolumn{6}{|l|}{ Individual characteristics } \\
\hline Age & - & $\begin{array}{c}0.1137^{\star * \star} \\
(0.0057)\end{array}$ & - & $\begin{array}{c}0.1139^{* \star *} \\
(0.0057)\end{array}$ & $\begin{array}{c}0.1139 * \star \star \\
(0.0057)\end{array}$ \\
\hline Age squared & - & $\begin{array}{l}-0.1057^{\star * *} \\
(0.0065)\end{array}$ & - & $\begin{array}{l}-0.1061^{* * *} \\
(0.0065)\end{array}$ & $\begin{array}{l}-0.1061^{\star \star *} \\
(0.0065)\end{array}$ \\
\hline Primary school & - & Reference & - & Reference & Reference \\
\hline Secondary school & - & $\begin{array}{c}0.0537^{\star \star *} \\
(0.0213)\end{array}$ & - & $\begin{array}{c}0.0523^{\star \star \star} \\
(0.0213)\end{array}$ & $\begin{array}{l}0.0524^{\star * *} \\
(0.0213)\end{array}$ \\
\hline University degree & - & $\begin{array}{l}-0.1352^{* * *} \\
(0.0221)\end{array}$ & - & $\begin{array}{l}-0.1502^{\star \star *} \\
(0.0222)\end{array}$ & $\begin{array}{l}-0.1501^{* * *} \\
(0.0222)\end{array}$ \\
\hline Married & - & $\begin{array}{c}0.3137^{\star * \star} \\
(0.0158)\end{array}$ & - & $\begin{array}{l}0.3231^{* * *} \\
(0.0156)\end{array}$ & $\begin{array}{c}0.3230^{\star * \star} \\
(0.0156)\end{array}$ \\
\hline Children & - & $\begin{array}{c}0.0463^{* * *} \\
(0.0174)\end{array}$ & - & $\begin{array}{c}0.0452^{* * *} \\
(0.0173)\end{array}$ & $\begin{array}{c}0.0453^{\star * *} \\
(0.0173)\end{array}$ \\
\hline \multicolumn{6}{|l|}{$\begin{array}{l}\text { Local labour market } \\
\text { characteristics }\end{array}$} \\
\hline Local unemployment rate & - & - & - & - & $\begin{array}{l}0.0255 \\
(0.0292)\end{array}$ \\
\hline Local income tax rate & - & - & - & - & $\begin{array}{c}0.0084 \\
(0.0313)\end{array}$ \\
\hline $\begin{array}{l}\text { Variance region of origin and } \\
\text { year of immigration }\end{array}$ & 0.58 & 0.52 & 0.58 & 0.52 & 0.52 \\
\hline Variance labour market area & - & - & 0.20 & 0.19 & 0.19 \\
\hline Total variance & 0.58 & 0.52 & 0.78 & 0.71 & 0.71 \\
\hline ICC (total) & $15.0 \%$ & $13.6 \%$ & $19.2 \%$ & $17.8 \%$ & $17.8 \%$ \\
\hline DIC & 164,589 & 162,508 & 164,348 & 162,238 & 162,237 \\
\hline Number of observations & & & 473,958 & & \\
\hline
\end{tabular}

Turning to females, Figure B2 reveals large variations between different immigrant groups. A high self-employment propensity is found among female immigrants from the Middle East, from Western Europe and among early immigrants from Eastern Europe. Just as for men there are large variations between different cohorts of immigrants, and just as for men a low selfemployment propensity is found for the 2001-2007 cohort. The only exception for this is females who immigrated from Western Europe during the period 2001 to 2007. The self- 
employment probability among females in this cohort is above the average self-employment probability in our sample.

The estimations presented in Table 4 reveal that about 15 per cent $(15.0$ per cent in Model 1 and 13.6 per cent in Model 2) of the total variance in the propensity of being self-employed is explained by ethnic origin and point of time for immigration. When we add a random effect for local labour market areas to the specification, the share explained by the model increases to about 20 per cent of the total variance (19.2 per cent in Model 3, 17.8 per cent in Model 4 and 17.8 per cent in Model 5). As for men, differences by region of origin and cohort are more important determinants than differences between local labour market areas. Thus, the importance of ethnic background, point of time for immigration and local labour market areas looks about the same for females as for males.

\section{Discussion and conclusions}

This paper has been devoted to a study of how ethnic origin and local labour markets influence self-employment propensities among immigrants in Sweden. In line with previous research we find differences in the propensity to be self-employed between immigrants and natives and among different immigrant groups. We also find large differences in selfemployment propensities between different immigrant cohorts originating from the same region.

When quantifying the role of ethnic background, point of time for immigration and local market conditions for self-employment propensities we find that the self-employment decision is to a major extent guided by factors unobservable in register data. Such factors might e.g. be individual entrepreneurial ability, access to financial capital and different kinds of discrimination by customers on the local labour market. The individual's ethnic background and point of time for immigration play a smaller role for the self-employment decision but are more important than local market conditions.

The result underlines that future research on immigrant self-employment should be conducted by methods that help us to further understand the mechanisms behind the immigrant selfemployment decisions. Such methods might e.g. be different types of surveys in which immigrant entrepreneurs are approached with questions about their motives behind their selfemployment decision and further also about which possibilities and obstacles they face when becoming self-employed and also in their careers as self-employed. 


\section{References}

Andersson-Joona, P. (2010). Exits from self-employment: Is there a native-immigrant difference in Sweden?. International Migration Review, 44, 539-559.

Andersson, L. \& Hammarstedt, M. (2010). Intergenerational transmissions in immigrant selfemployment: Evidence from three generations. Small Business Economics, 34, 261-276.

Andersson, L. \& Hammarstedt, M. (2011a). Transmission of self-employment across immigrant generations: The importance of ethnic background and gender. Review of Economics of the Household, forthcoming.

Andersson, L. \& Hammarstedt, M. (2011b). Ethnic enclaves, networks and self-employment among immigrants in Sweden. International Migration, forthcoming.

Borjas, G. J. (1986). The self-employment experience of immigrants. Journal of Human Resources, 21, 487-506.

Clark, K. \& Drinkwater, S. (2000). Pushed out or pulled in? Self-employment among ethnic minorities in England and Wales. Labour Economics, 7, 603-628.

Constant, A. \& Zimmermann, K. F. (2006). The making of entrepreneurs in Germany: are immigrants and natives alike?. Small Business Economics, 26, 279-300.

Fairlie, R. W. (1999). The absence of the African-American owned businesses: an analysis of the dynamics of self-employment. Journal of Labor Economics, 17, 80-108.

Fairlie, R. W. \& Meyer, B. D. (1996). Ethnic and racial self-employment differences and possible explanations. Journal of Human Resources, 31, 757-793.

Gelman, A. \& Hill, J. (2007) Data Analysis Using Regression and Multilevel/Hierarchical Models, New York: Cambridge.

Hammarstedt, M. (2001a). Immigrant self-employment in Sweden - its variation and some possible determinants. Entrepreneurship and Regional Development, 13, 147-161.

Hammarstedt, M. (2001b). Making a living in a new country. PhD thesis. Växjö University.

Hammarstedt, M. (2004). Self-employment among immigrants in Sweden - an analysis of intragroup differences. Small Business Economics, 23, 115-126.

Hammarstedt, M. (2006). The predicted earnings differential and immigrant self-employment in Sweden. Applied Economics, 38, 619-630.

Hammarstedt, M. \& Shukur, G. (2009). Testing the home-country self-employment hypothesis on immigrants in Sweden. Applied Economics Letters, 16, 745-748.

Hout, M. \& Rosen, H. (2000). Self-employment, family background, and race. Journal of Human Resources, 35, 670-691. 
Hox, J. (2002) Multilevel Analysis: Techniques and Applications, Mahwah, New Jersey: Lawrence Erlbaum Associates, Publishers.

Kloosterman, R., van der Leun, J. \& Rath, J. (1998). Across the border. Immigrants' economic opportunities, social capital and informal business activities. Journal of Ethnic and Migration Studies, 24, 249-268.

Kloosterman, R. \& Rath, J. (2001). Immigrant entrepreneurs in advanced economies: mixed embededdness further explored. Journal of Ethnic and Migration Studies, 27, 189-202.

Le, A. T. (2000). The determinants of immigrant self-employment in Australia. International Migration Review, 34, 183-214.

Ohlsson, H., Broomé, P. \& Bevelander, P. (2011). The self-employment among immigrants and natives in Sweden. Entrepreneurship and Regional Development, forthcoming.

Parker, C. (2004) The Economics of Self-Employment and Entrepreneurship, New York: Cambridge University Press.

Ram, M., Theodorakoupoulos, N. \& Jones, T. (2008). Forms of capital, mixed embeddedness and Somali enterprise. Work, Employment \& Society, 22, 427-446.

SCB, MIS 2007:1, Regional divisions in Sweden on 1 January 2007.

Yuengert, A. M. (1995). Testing hypotheses of immigrant self-employment. Journal of Human Resources, 30, 194-204. 
Appendix A: Local labour markets in Sweden 2007 (SCB, MSI 2007:1)

\begin{tabular}{|c|c|c|c|c|c|}
\hline Code & $\begin{array}{l}\text { Number } \\
\text { (in article) }\end{array}$ & Local labour market & Code & $\begin{array}{l}\text { Number } \\
\text { (in article) }\end{array}$ & Local labour market \\
\hline LA301 & 1 & Stockholm & LA345 & 45 & Örebro \\
\hline LA302 & 2 & Nyköping-Oxelösund & LA346 & 46 & Karlskoga \\
\hline LA303 & 3 & Eskilstuna & LA347 & 47 & Västerås \\
\hline LA304 & 4 & Linköping & LA348 & 48 & Fagersta \\
\hline LA305 & 5 & Norrköping & LA349 & 49 & Vansbro \\
\hline LA306 & 6 & Gislaved & LA350 & 50 & Malung \\
\hline LA307 & 7 & Jönköping & LA351 & 51 & Mora \\
\hline LA308 & 8 & Värnamo & LA352 & 52 & Falun-Borlänge \\
\hline LA309 & 9 & Vetlanda & LA353 & 53 & Avesta \\
\hline LA310 & 10 & Tranås & LA354 & 54 & Ludvika \\
\hline LA311 & 11 & Älmhult & LA355 & 55 & Ljusdal \\
\hline LA312 & 12 & Markaryd & LA356 & 56 & Gävle \\
\hline LA313 & 13 & Växjö & LA357 & 57 & Söderhamn \\
\hline LA314 & 14 & Ljungby & LA358 & 58 & Bollnäs \\
\hline LA315 & 15 & Emmaboda & LA359 & 59 & Hudiksvall \\
\hline LA316 & 16 & Kalmar & LA360 & 60 & Ånge \\
\hline LA317 & 17 & Oskarshamn & LA361 & 61 & Sundsvall \\
\hline LA318 & 18 & Västervik & LA362 & 62 & Kramfors \\
\hline LA319 & 19 & Vimmerby & LA364 & 64 & Örnsköldsvik \\
\hline LA320 & 20 & Gotland & LA365 & 65 & Strömsund \\
\hline LA321 & 21 & Olofström & LA366 & 66 & Härjedalen \\
\hline LA322 & 22 & Karlskrona & LA367 & 67 & Östersund \\
\hline LA323 & 23 & Malmö-Lund & LA368 & 68 & Malå \\
\hline LA324 & 24 & Kristianstad & LA369 & 69 & Storuman \\
\hline LA325 & 25 & Simrishamn-Tomelilla & LA370 & 70 & Sorsele \\
\hline LA326 & 26 & Halmstad & LA371 & 71 & Dorotea \\
\hline LA327 & 27 & Falkenberg & LA372 & 72 & Vilhelmina \\
\hline LA328 & 28 & Varberg & LA373 & 73 & Åsele \\
\hline LA329 & 29 & Bengtsfors & LA374 & 74 & Umeå \\
\hline LA330 & 30 & Lidköping-Götene & LA375 & 75 & Lycksele \\
\hline LA331 & 31 & Göteborg & LA376 & 76 & Skellefteå \\
\hline LA332 & 32 & Strömstad & LA377 & 77 & Arvidsjaur \\
\hline LA333 & 33 & Trollhättan & LA378 & 78 & Arjeplog \\
\hline LA334 & 34 & Borås & LA379 & 79 & Jokkmokk \\
\hline LA335 & 35 & Åmål & LA380 & 80 & Överkalix \\
\hline LA336 & 36 & Skövde & LA381 & 81 & Kalix \\
\hline LA337 & 37 & Torsby & LA382 & 82 & Övertorneå \\
\hline LA338 & 38 & Årjäng & LA383 & 83 & Pajala \\
\hline LA339 & 39 & Karlstad & LA384 & 84 & Gällivare \\
\hline LA340 & 40 & Filipstad & LA385 & 85 & Luleå \\
\hline LA341 & 41 & Hagfors & LA386 & 86 & Haparanda \\
\hline LA342 & 42 & Arvika & LA387 & 87 & Kiruna \\
\hline LA343 & 43 & Säffle & & & \\
\hline LA344 & 44 & Hällefors & & & \\
\hline
\end{tabular}




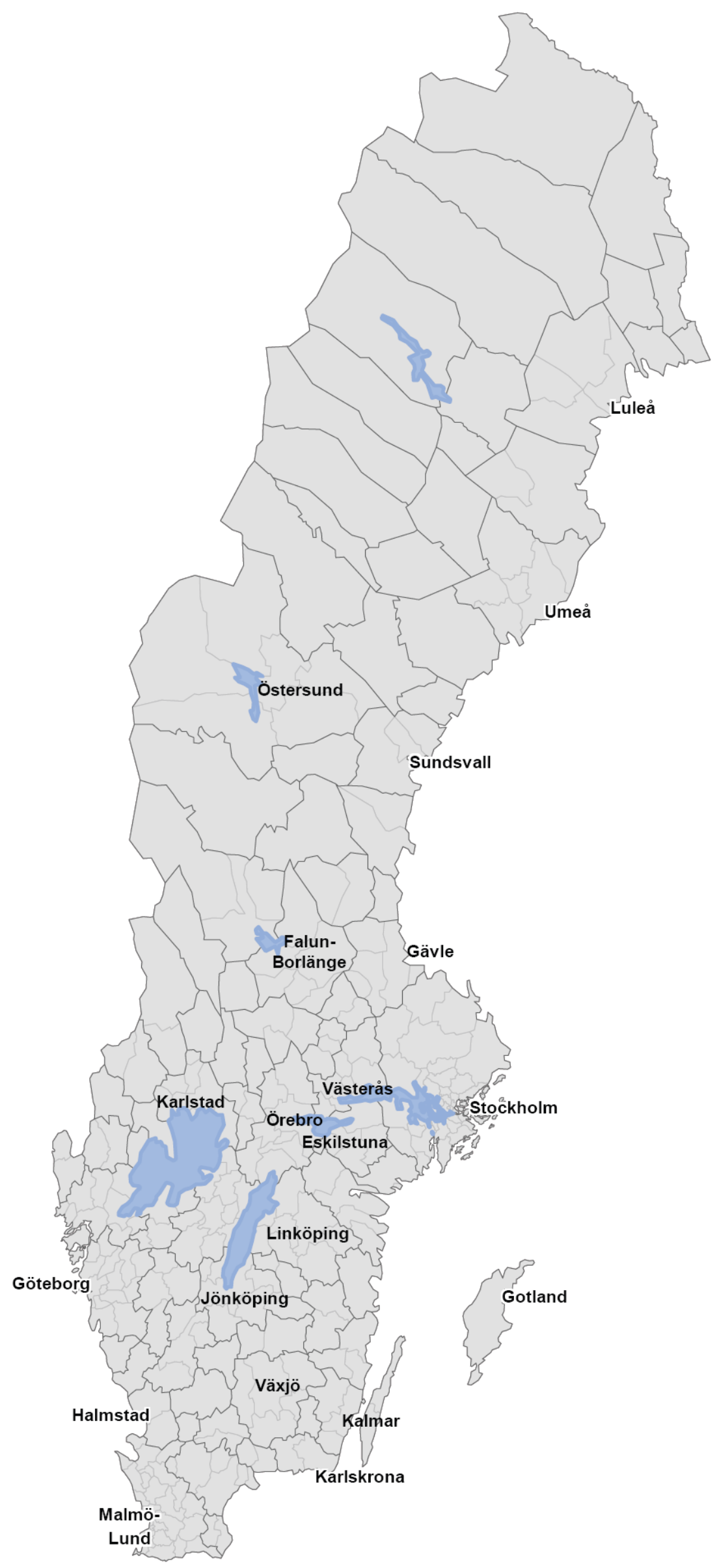




\section{Appendix B - Estimated random effects}

Figure B1: Estimated random effect of region of origin and year of immigration for men

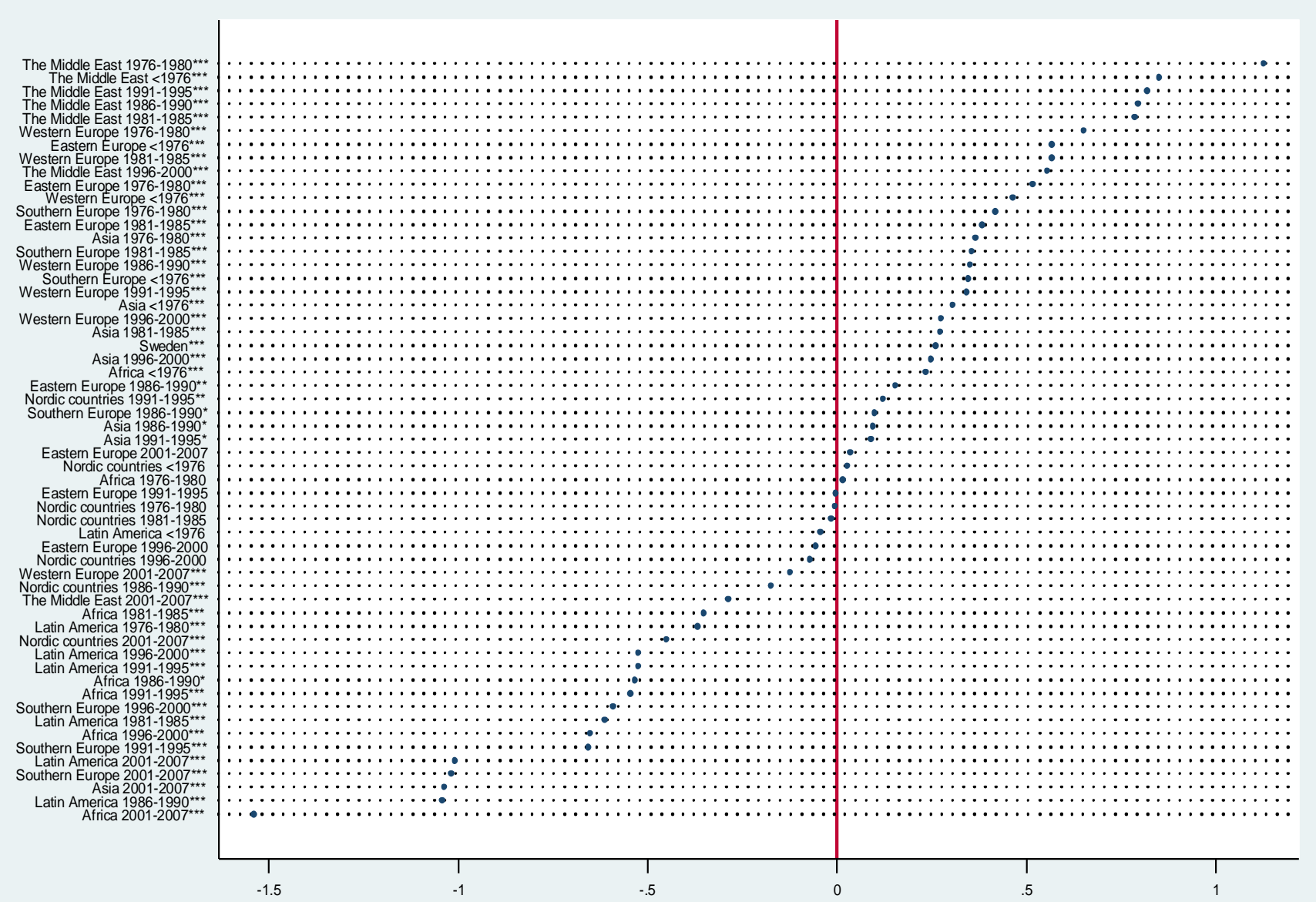

Note: *** indicates statistical significance at the 1-per cent level, "* at the 5-per cent level, and " at the 10-per cent level. 
Figure B2: Estimated random effect of region of origin and year of immigration for women

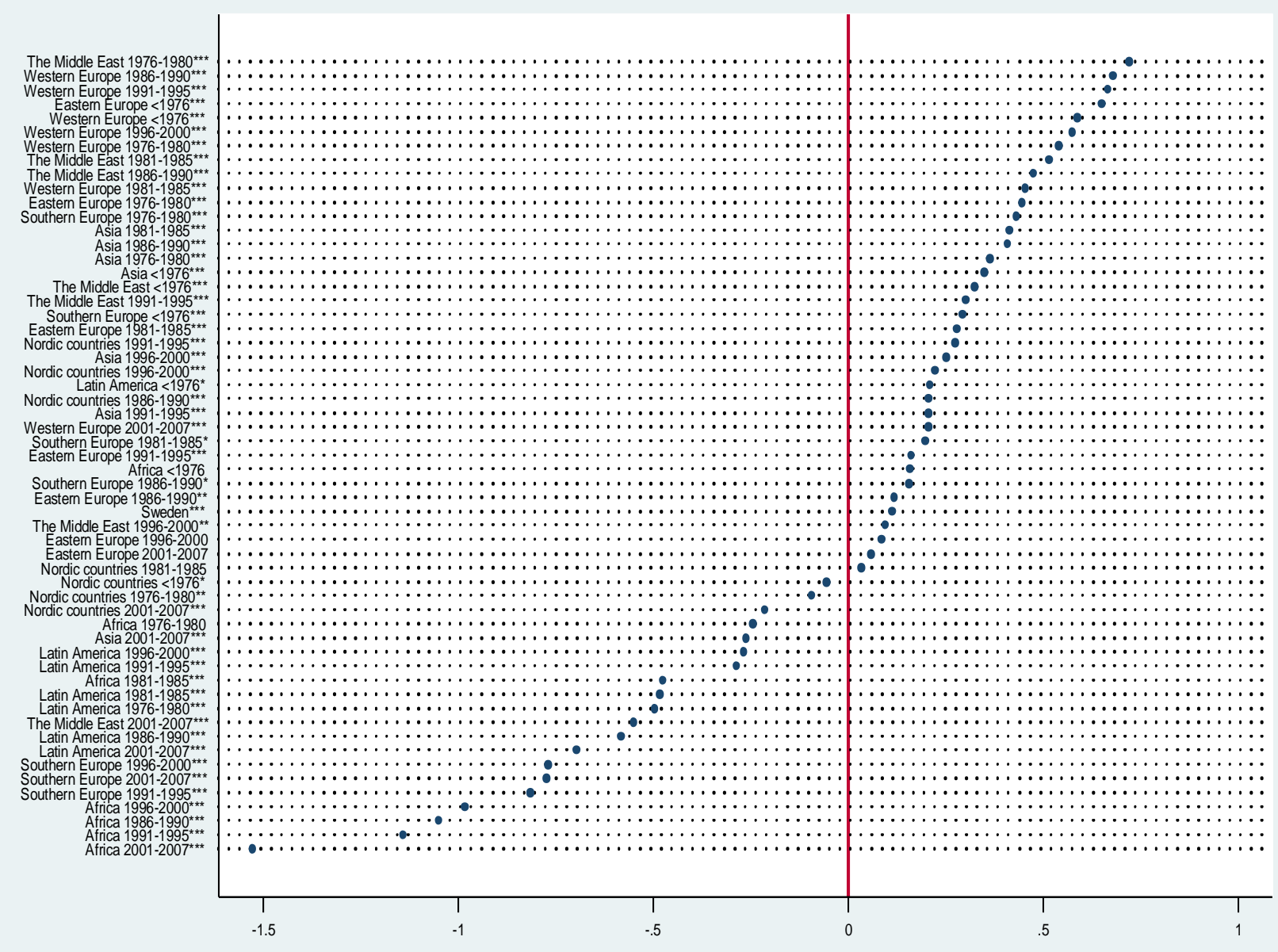

Note: *** indicates statistical significance at the 1-per cent level, "* at the 5-per cent level, and *at the 10-per cent level. 


\section{Appendix C:}

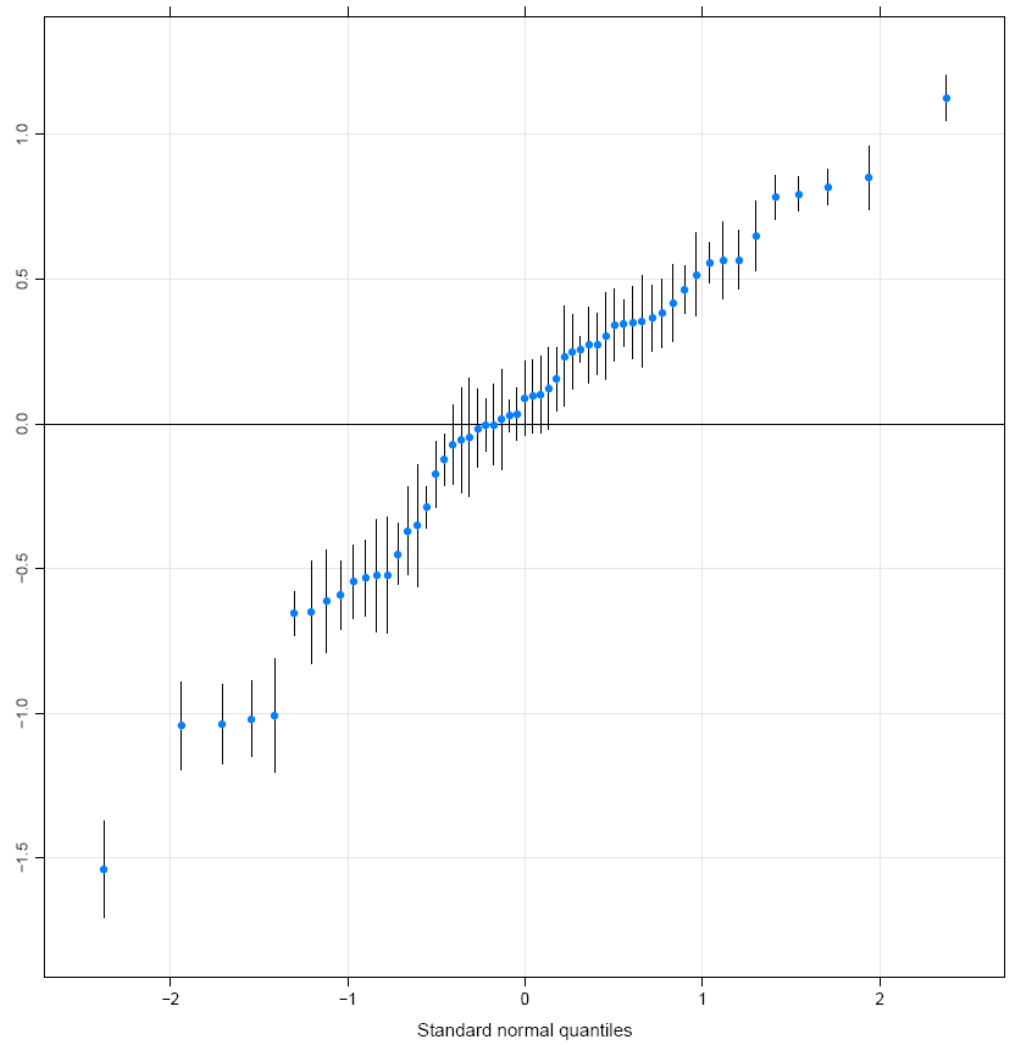

Figure CX: QQ-plot of region of residence and time of immigration for men (from Spec. 5)

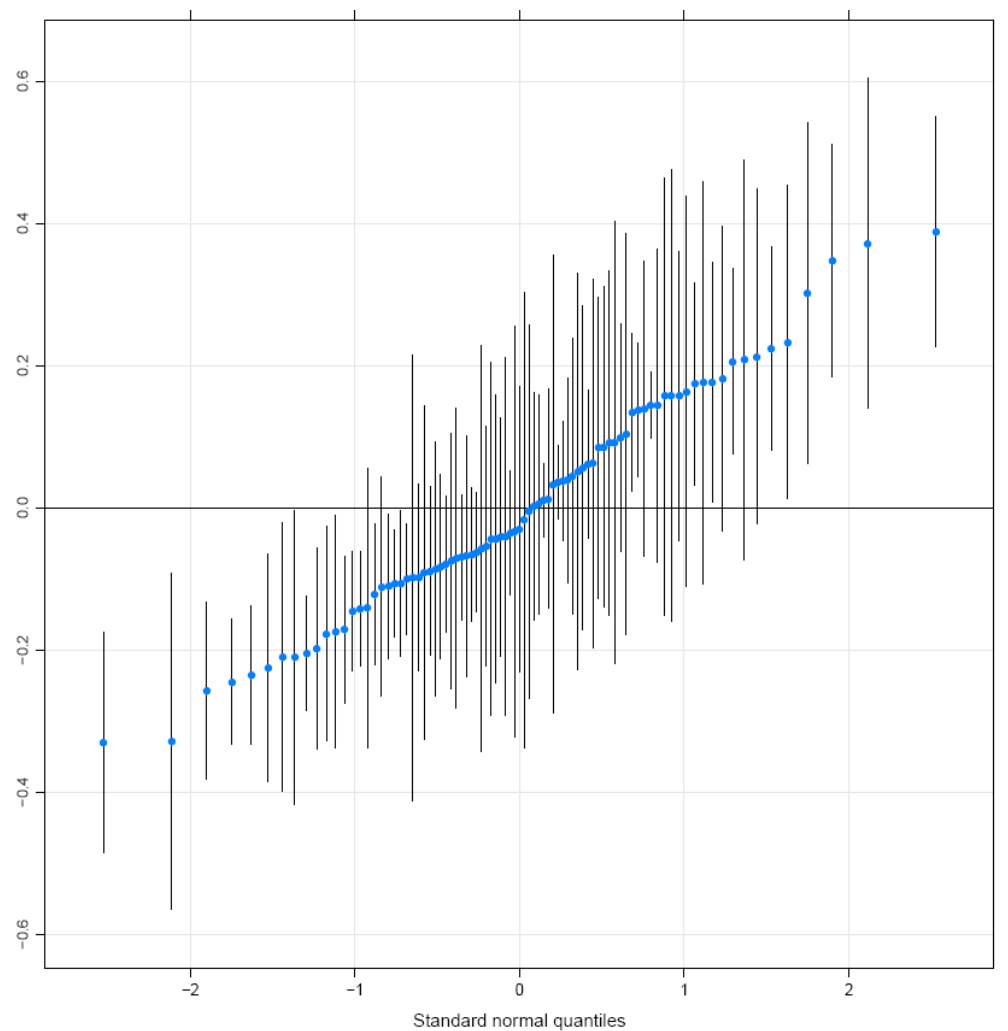

Figure CX: QQ-plot of local labour market region for men (from Spec. 5) 


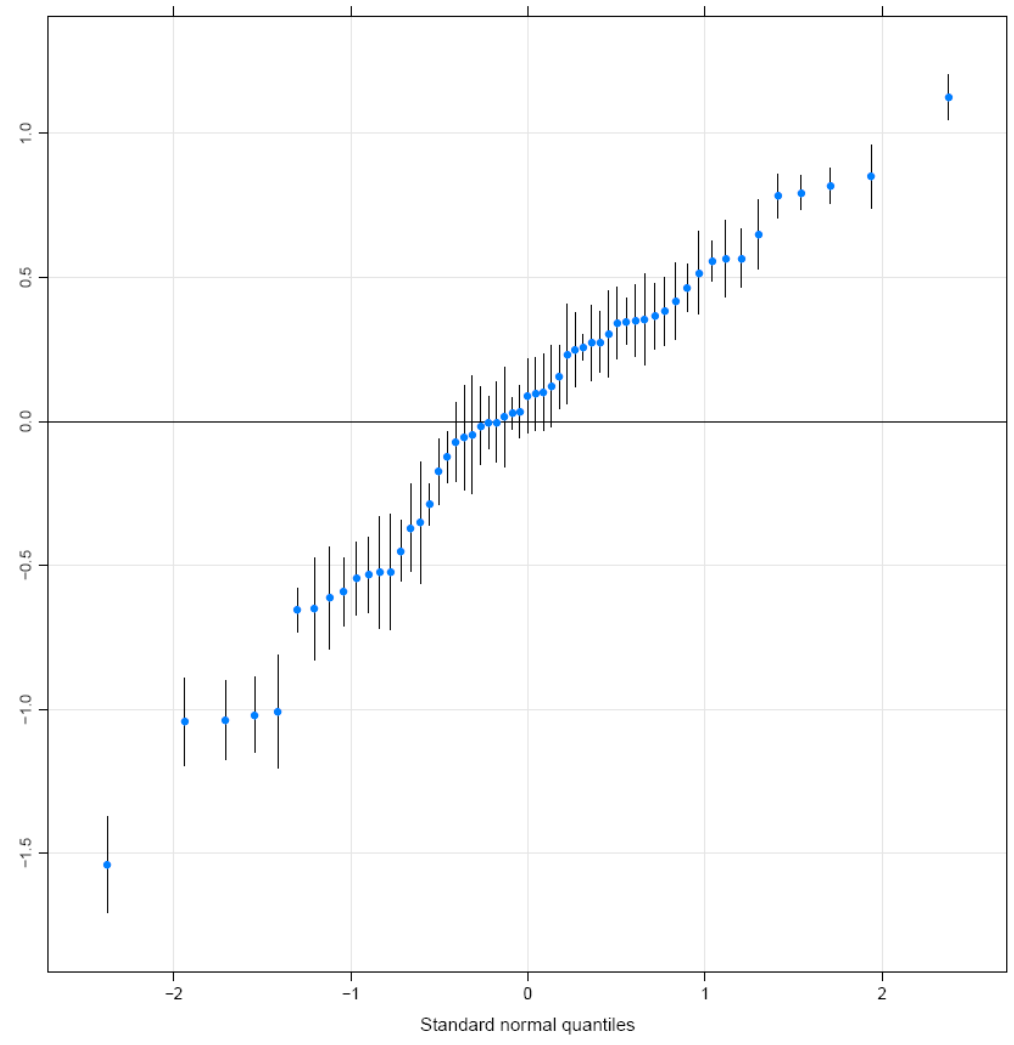

Figure CX: QQ-plot of region of residence and time of immigration for women (from Spec. 5)

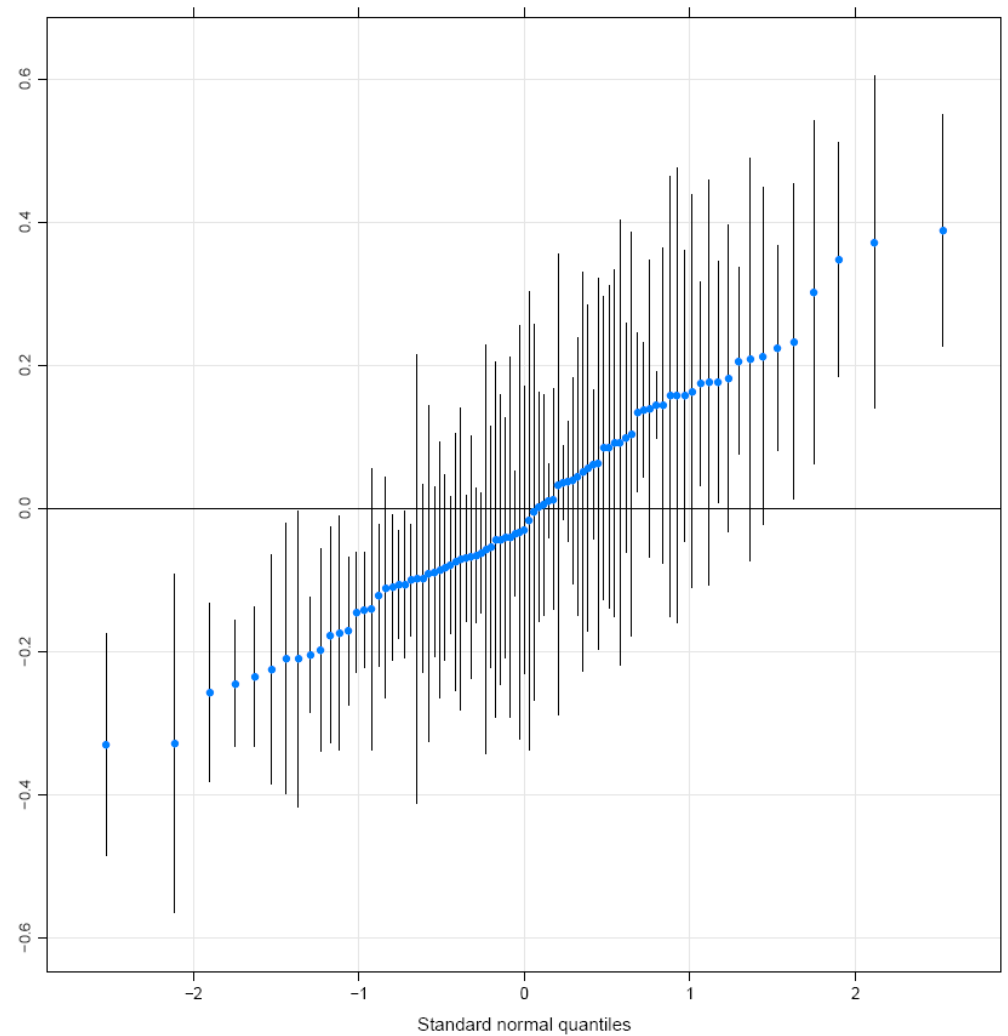

Figure CX: QQ-plot of local labour market region for women (from Spec. 5 